\title{
BADUSH DAM: PLANNED AND DESIGNED AS A PROTECTION DAM, NW IRAQ
}

\author{
VAROOJAn K. SisSAKIAN ${ }^{1 *}$, NASRAT AdAmo** and NADHIR AL-ANSARI*** \\ "Dept. of Natural Resource Engineering and Management, School of Science and Engineering, \\ University of Kurdistan Hewler, KRG, Kurdistan Region-Iraq \\ ${ }^{* *}$ Consultant Engineer, Norrköping-Sweden, \\ ${ }^{* * *}$ Dept. of Civil, Environmental and Natural Resources Engineering, Lulea University of \\ Technology, Lulea-Sweden,
}

(Accepted for Publication: December 8, 2020)

\begin{abstract}
Badush Dam is uncompleted combined earthfill and concrete dam, it is located on the Tigris River. The dam is planned and designed to be a protection dam downstream of the already existing Mosul Dam to protect population and infrastructure downstream of Mosul Dam. Thisa is attributed to the safety concerns of Mosul Dam which suffers from severe karstification in its foundation due to the presence of thick gypsum beds. The safety of Mosul Dam is a matter of debate since its construction and commissioning in 1986. The construction of Badush Dam started in 1988 and suspended in 1991, although (30 - 40) \% of the dam was already built. The geological setting of Badush Dam is almost similar to that of Mosul Dam. Therefore, the foundation of Badush Dam will suffer from the same problem which is karstification because they are located on gypsum beds which are the same rocks under the foundations of Mosul Dam. The thin inclined clay core and foundation treatment works indicate clearly that Badush Dam is designed to have temporary nature which is to contain the volume of Mosul Dam wave $(11 \times 11$ $\mathbf{k m}^{3}$ ) in case of collapse of Mosul Dam and to pass the wave downstream without flooding.
\end{abstract}

KEYWORDS: Badush Dam; Mosul Dam; Karstification; Karstified Foundations; Flooding.

\section{INTRODUCTION}

$\mathrm{B}^{\mathrm{a}}$ adush Dam is uncompleted earthfill dam planned, designed and constructed on the Tigris River as a protection dam to keep the safety of the community living downstream of the river and the present infrastructures if Mosul Dam collapses. Mosul Dam is constructed on the Tigris River northwest of Badush Dam by about $40 \mathrm{~km}$, and Badush Dam itself is located $16 \mathrm{~km}$ northwest of Mosul city (Fig. 1). Mosul Dam is the largest dam in Iraq with capacity of $11.11 \mathrm{~km}^{3}$, whose commissioning begun in 1986 . Since then and even before that, the foundations of the dam were suffering from active dissolution of karsts due to the presence of gypsum rocks of the Fatha Formation which are the same rocks at the foundations of Badush Dam (Sissakian et al., 2018 a and b, and 2019). Grouting was performed in Mosul Dam foundation and was planned for the foundations of Badush Dam. Grouting generally is one of the treatment methods of foundations of dams constructed in karst areas, which is performed to protect these foundations as an anti-seepage measure, and in these two cases from the dissolution of the karstified rocks (Thuro et al., 2000; Johnson, 2008; Bonaci et al., 2009; Milanović, 2011; Bonaci and Bonaci, 2013; Sissakian et al., 2014; Adamo et al., 2015 and U.S. Army Corps of Engineers, 2017).

The aim of this article is to elucidate the status of Badush Dam (although not completed) and to discuss whether it can perform as a protection dam in the case of failure of Mosul Dam. Moreover, to suggest what should be done to validate the aim of Badush Dam (in case it is decided to continue its construction) to fulfill its function as a protection dam.

\section{MATERIALS AND METHODS}

For the purpose of the current study, we have used the available geological and topographical maps of different scales, satellite images of high resolution and tens of published articles as the subject of the study has required. All these materials were studied thoroughly and interpreted as an integrated study to achieve the aim of the current study.

f.khajeek@ukh.edu.krd, nasrat.adamo@gmail.com, nadhir.alansari@ltu.se 


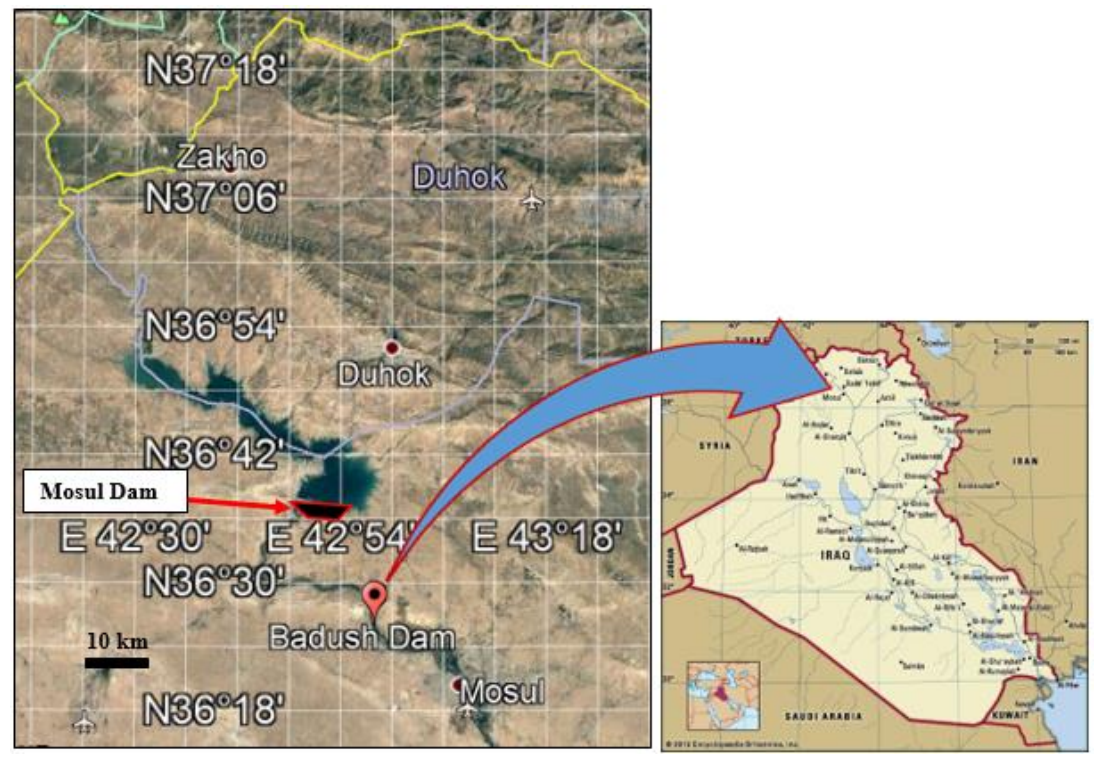

Fig. (1): Location map of Badush Dam

\section{GEOLOGICAL SETTING}

The geological setting of Badush Dam site and surroundings is briefed using available data, including: Geomorphology, Tectonics and Structural Geology, and Stratigraphy depending on field reports of Hagopian and Valupec (1977); Muhi Adeen et al. (1977); Yacoub et al. (2012); Fouad (2012); Fouad et al. (2003) and Sissakian et al. (2013). The geologic map of Badush Dam site and near surrounding is presented in Fig.

(2).

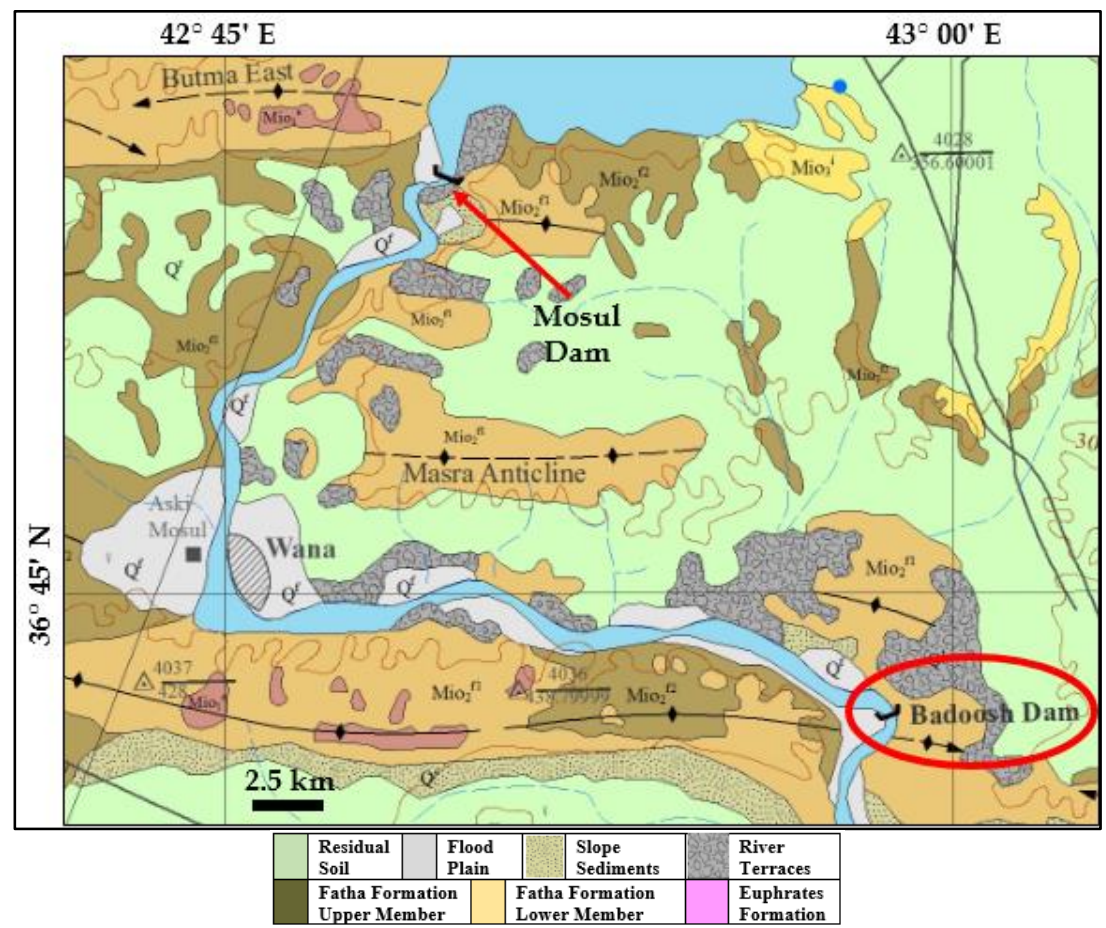

Fig. (2): Geological map of Badush and Mosul dams' sites (After Sissakian et al. 2013).

f.khajeek@ukh.edu.krd, nasrat.adamo@gmail.com, nadhir.alansari@ltu.se

$32{ }^{1}$ Corresponding author: University of Kurdistan Hewler 


\subsection{Geomorphology}

The main geomorphological units at the dam site and near surrounding are briefed hereinafter.

- Units of Alluvial Origin: Flood plain and river terraces are well developed at the dam site and along both banks of the Tigris River. The sediments of both units are used in the construction of different parts of the dam.

- Units of Structural - Denudational Origin: The depositional and erosional glacis are rich in gypsiferous cement. Also, anticlinal ridges and flat irons are well developed in the Fatha Formation.
- Solution Units: Sinkholes of different shapes, sizes and activities are well developed in both the Euphrates and Fatha formations. The gypsum and limestone beds of the Fatha Formation on which the foundations of the dam are located suffer from very active karstification, which has dissolved the beds of the Fatha Formation. According to Sissakian and Abdul Jab'bar (2005) these karstified beds exhibit false dipping towards the karst forms; due to collapse of the beds towards the existing caves and fractures beneath them (Fig.

$3)$.

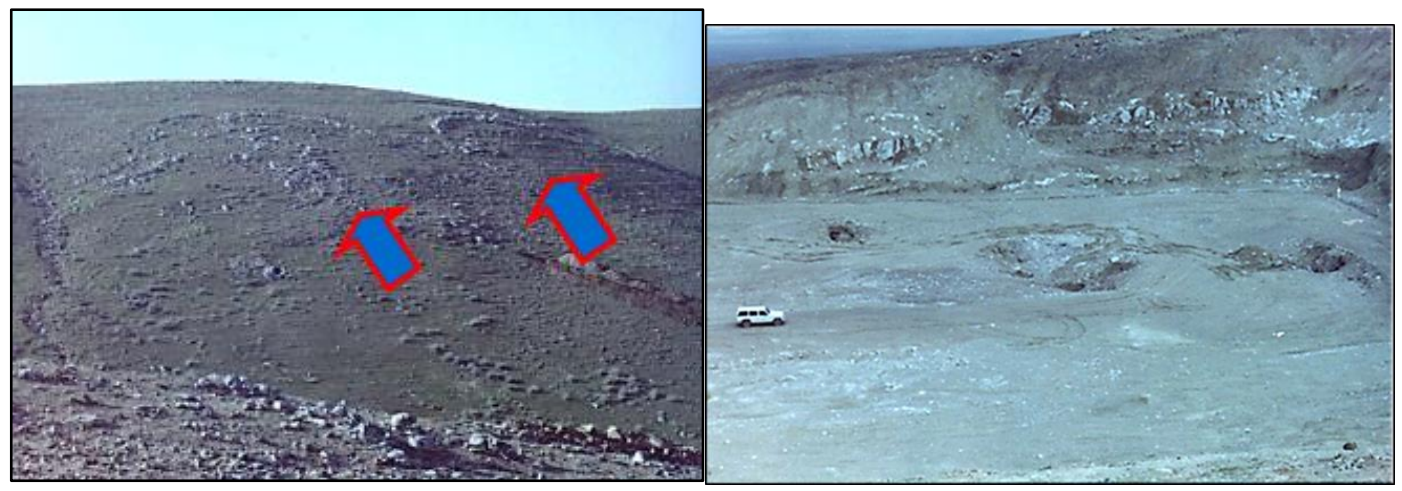

Fig. (3): Left) False dipping of limestone and gypsum beds due to underneath karstification, Right) An open site showing the karstified gypsum and limestone beds, note the sinkholes in the floor of the site which is about $20 \mathrm{~km}$ south of Badush Dam and within the same geological formation on which Badush Dam was planned to be constructed.

\subsection{Tectonics and Structural Geology}

Badush Dam is located on Allan anticline which is located in the Low Folded Zone of the Outer Platform, which belongs to the Arabian Plate (Fouad, 2012). Allan anticline is a double plunging anticline with almost $\mathrm{E}-\mathrm{W}$ trend; the axis of the dam is located along the axis of the anticline (Fig. 4). The southern limb is steeper, and the eastern plunge is east of the Tigris River, i.e. east of Badush Dam (Fig. 2).

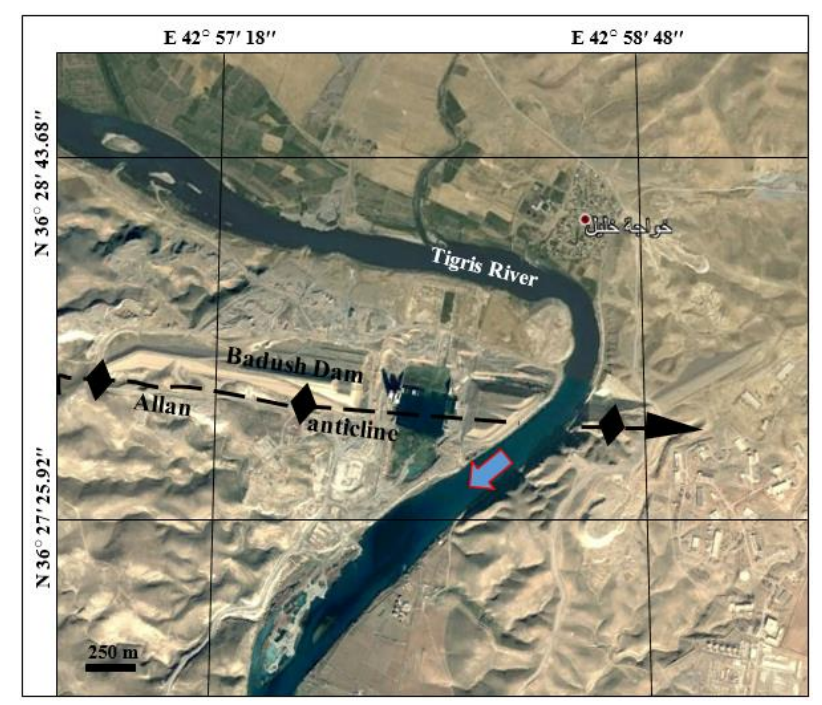

Fig. (4): Satellite image showing Allan anticline and the constructed part of Badush Dam

f.khajeek@ukh.edu.krd, nasrat.adamo@gmail.com, nadhir.alansari@ltu.se 


\subsection{Stratigraphy}

The exposed geological formations at Badush Dam site and the reservoir area with the main Quaternary sediments are briefly mentioned hereinafter and presented in Figure (2).

- Euphrates Formation (Lower Miocene): The formation is exposed at the core of Allan anticline; it consists of well bedded, hard limestone and marly limestone. The rocks are highly karstified. The thickness of the formation ranges from $(26-50) \mathrm{m}$.

- Fatha Formation (Middle Miocene): The formation is widely exposed at Allan anticline and surrounding areas; it is divided into Lower and Upper Members. Both members consist of cyclic sediments of green marl, limestone and gypsum. The gypsum and limestone beds are highly karstified (Fig. 3). The thickness of the formation ranges from $117 \mathrm{~m}$ at the left bank to $300 \mathrm{~m}$ at the right bank.

- River Terraces (Pleistocene): The terraces are accumulated at different parts, along the Tigris River. Three levels are developed. The pebbles of the terraces are cemented by gypsiferous and sandy cement which cause severe problems when they are used in concrete if they are used without proper washing. The thickness ranges between $(5-8) \mathrm{m}$.

- Slope sediments (Late Pleistocene Holocene): These are well developed along the foothills of Allan Mountain (anticline) as a narrow belt surrounding the mountain. They consist of rock fragments mixed with gypsiferous soil; partly cemented. The thickness ranges from $(1-12) \mathrm{m}$.

- Residual Soil (Holocene): The residual soil covers large parts of the surroundings of Badush Dam (Fig. 2). It is reddish brown clayey soil with rock fragments. In areas covered by the Fatha Formation, the residual soil is gypsiferous. The thickness ranges from $(1-3) \mathrm{m}$.

- Flood Plain Sediments (Holocene): The flood plain sediments are developed along both banks of the Tigris River. The sediments consist of sand, silt and clay, locally are gypsiferous. Large quantities of the flood plain sediments were used as construction material (aggregate) in different parts of Badush Dam. The thickness ranges from $(2-5) \mathrm{m}$.

\section{BADUSH DAM}

\subsection{General}

Badush Dam is an earthfill- buttress concrete dam located on the Tigris River. Construction of this dam was proposed as a protection dam to contain Mosul Dam flood wave if this dam would fail. The decision to build the dam was taken in 1987 after having problems in completing the grout curtain of Mosul dam. A previous study in 1984 and many others have shown the great dimensions of catastrophe if Mosul Dam failed (Swiss Consultant Consortium, 1985; Al-Ansari et al., 2015; Adamo et al., 2015 a and 2017). Construction of the dam was abandoned in 1991 due to the economic embargo on Iraq after the first Gulf War and was not resumed ever since. This dam would act as flood retaining structure to protect from the resulting flood wave of $11 \times 11 \mathrm{~km}^{3}$ of water in case of Mosul Dam failure which will form a maximum probable flood (Mosul Dam) $2700 \mathrm{~m}^{3} / \mathrm{sec}$. Layout of the dam is shown in Figure (5), and design parameter in Table (1). However, the already completed parts of Badush Dam ranges from (30 - 40) \% (Fig. 6) of the total dam works.

The design of Badush Dam indicates clearly the temporary nature of its use from elevation $260 \mathrm{~m}$ (a.s.l.) upward; which is reflected in the thin inclined clay core and other embankment details. Moreover, the designer (ENERGPROJECT, 1988) had assumed that the part of the dam above elevation $260 \mathrm{~m}$ (a.s.l.) will function for few months only which is the duration needed to pass the flood wave of collapsed Mosul Dam. It is also the time needed to empty the reservoir quickly. The same thing was also very clear in the design of the foundation treatment works. 


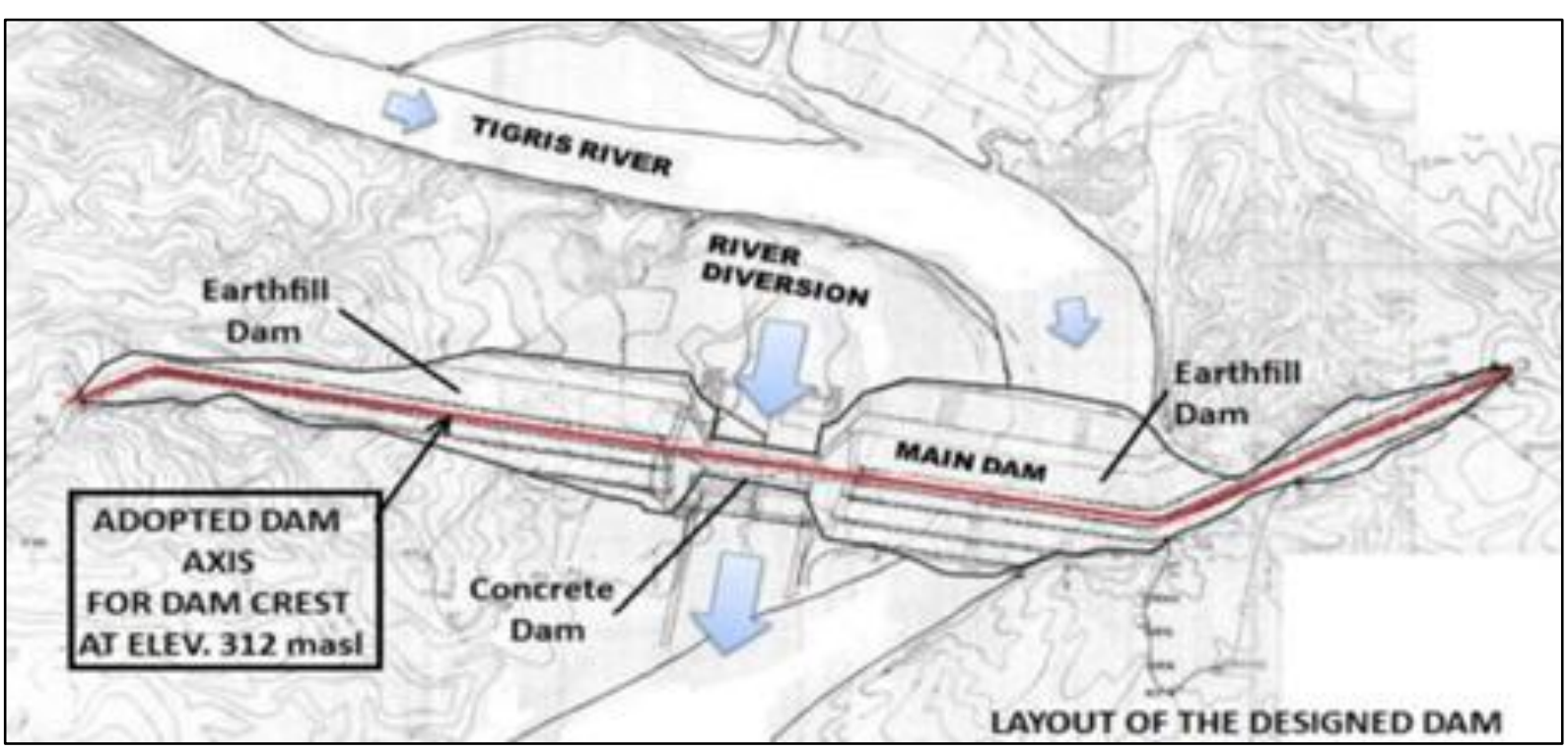

Fig. (5): Layout of Badush Dam (ENERGPROJECT, 1988)

Table (1): General data of the proposed Badush Dam

\begin{tabular}{|c|c|c|}
\hline No. & General data of Badush Dam & Units \\
\hline 1 & Reservoir capacity & $1.0 \times 10^{10} \mathrm{~m}^{3}$ \\
\hline 2 & Annual average discharge & $667 \mathrm{~m}^{3} / \mathrm{sec}$ \\
\hline 3 & Maximum probable flood (Mosul Dam) & $2700 \mathrm{~m}^{3} / \mathrm{sec}$ \\
\hline 4 & Flood with $0.01 \%$ probability at Mosul Dam & $12000 \mathrm{~m}^{3} / \mathrm{sec}$ \\
\hline 5 & $\begin{array}{l}\text { Design flood during operation (Routed through Mosul Dam to be passed through Badush } \\
\text { Dam) }\end{array}$ & $8000 \mathrm{~m}^{3} / \mathrm{sec}$ \\
\hline 6 & Maximum reservoir level (in case of Mosul Dam failure) & $307 \mathrm{~m}$ (a.s.I.) \\
\hline 7 & Design flood level for the normal case & $250 \mathrm{~m}$ (a.s.l.) \\
\hline 8 & Minimum reservoir level for the normal case & $243.8 \mathrm{~m}$ (a.s.l.) \\
\hline 9 & Spillway capacity & $4000 \mathrm{~m}^{3} / \mathrm{sec}$ \\
\hline 10 & Number of bottom outlets & 8 \\
\hline 11 & Total bottom outlets capacity & $8000 \mathrm{~m}^{3} / \mathrm{sec}$ \\
\hline 12 & Dam crest level & $312 \mathrm{~m}$ (a.s.I.) \\
\hline 13 & Maximum height of the earthfill dam & $92 \mathrm{~m}$ (a.s.I.) \\
\hline 14 & Length of the dam crest & $3.370 \mathrm{~km}$ \\
\hline 15 & Crest level of the concrete dam & $294.7 \mathrm{~m}$ (a.s.l.) \\
\hline 16 & Maximum height of the concrete dam & $102 \mathrm{~m}$ \\
\hline 17 & Length of the concrete dam & $248 \mathrm{~m}$ \\
\hline 18 & Installed capacity of the power station & $170 \mathrm{Mw}$ \\
\hline
\end{tabular}

\subsection{Problems Facing Badush Dam}

Badush Dam is located within an area where the Fatha Formation is exposed which includes karstified gypsum and limestone beds; therefore, the foundations of the dam suffer from karstification, which is the same case of Mosul Dam. 

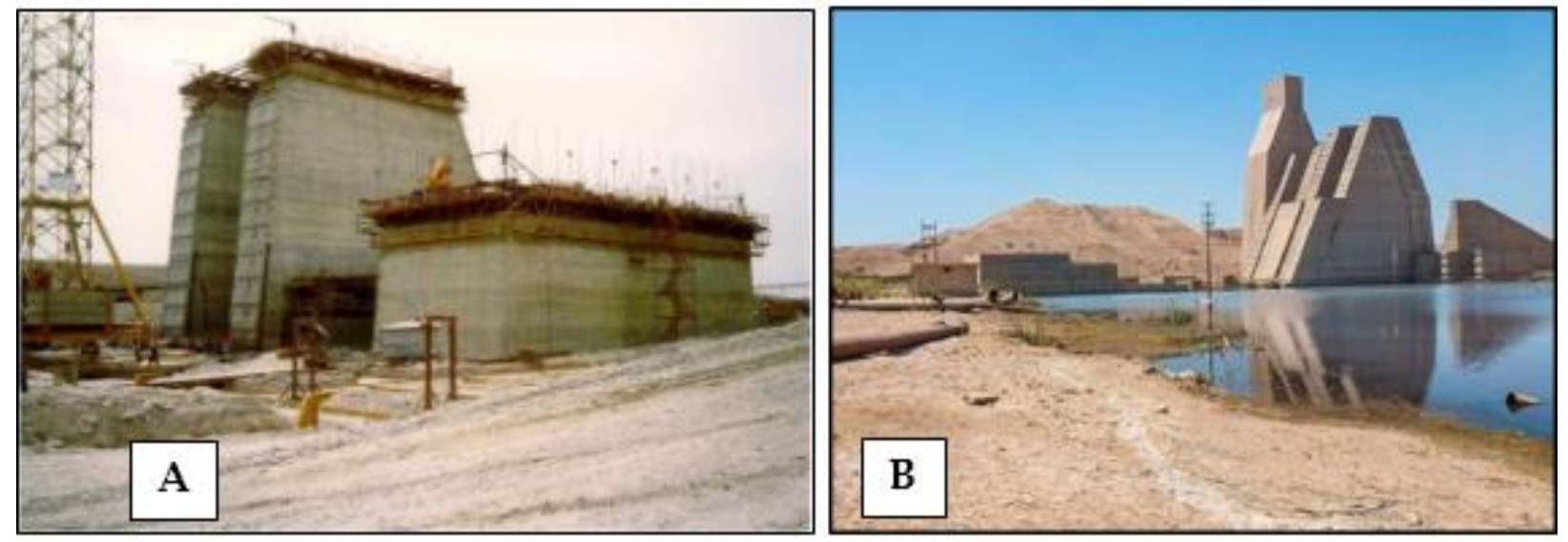

Fig. (6): Badush Dam, A) The concrete part during construction,

B) Abandoned concrete part of the dam

The problems of Mosul Dam are well studied and presented in many published papers (AlAnsari et al., 2015; Sissakian et al., 2014, 2015 and 2016; Adamo et al., 2015 b). Therefore, the same problems which Mosul Dam suffer from will be present at Badush Dam; if the construction of the dam will be restarted. This is because the exposed geological formations and even in subsurface are the same at both dam sites (Fig. 2). The problems will appear in Badush Dam unless the suggestions given by Sissakian et al. (2017) are considered.

\subsection{Badush Dam as a Protection Dam}

The concept of Badush Dam performance in case of Mosul Dam failure is shown in (Fig. 7)). During period from 2006 to 2013 various suggestions and revisions were carried out on the validity of Badush Dam purpose and its design. The outcome was conflicting opinions, between changing the dam into run of river low power generation dam and stripping it from the protection function, and at the same time build a huge diaphragm wall in Mosul Dam, or keeping the dam as it was formulated but perform major changes of design to ensure its safety (MWH Global, 2007; EPE, 2009 a and b; EDR, 2014).

It is clear from Fig. (7) that Badush Dam in its first phase with height at elevation of $260 \mathrm{~m}$ (a.s.l.) cannot perform as a protection dam in case of the failure of Mosul Dam (Fig. 7 B). However, to perform as a protection dam, the height should be raised to elevation $312 \mathrm{~m}$ (a.s.l.) (Fig. 7 C). Moreover, the following actions should be performed: 1) The grout curtain prescribed in Badush Dam design would not work and a diaphragm wall would be needed if this dam is to be completed; 2) Other major modifications on the design should also be done, especially the thickness of the core, and 3) In order to avoid any further surprises as were faced in Mosul Dam, a complete new and very extensive geological investigation of the foundation and reservoir sites has to be done first (Sissakian et al., 2019).

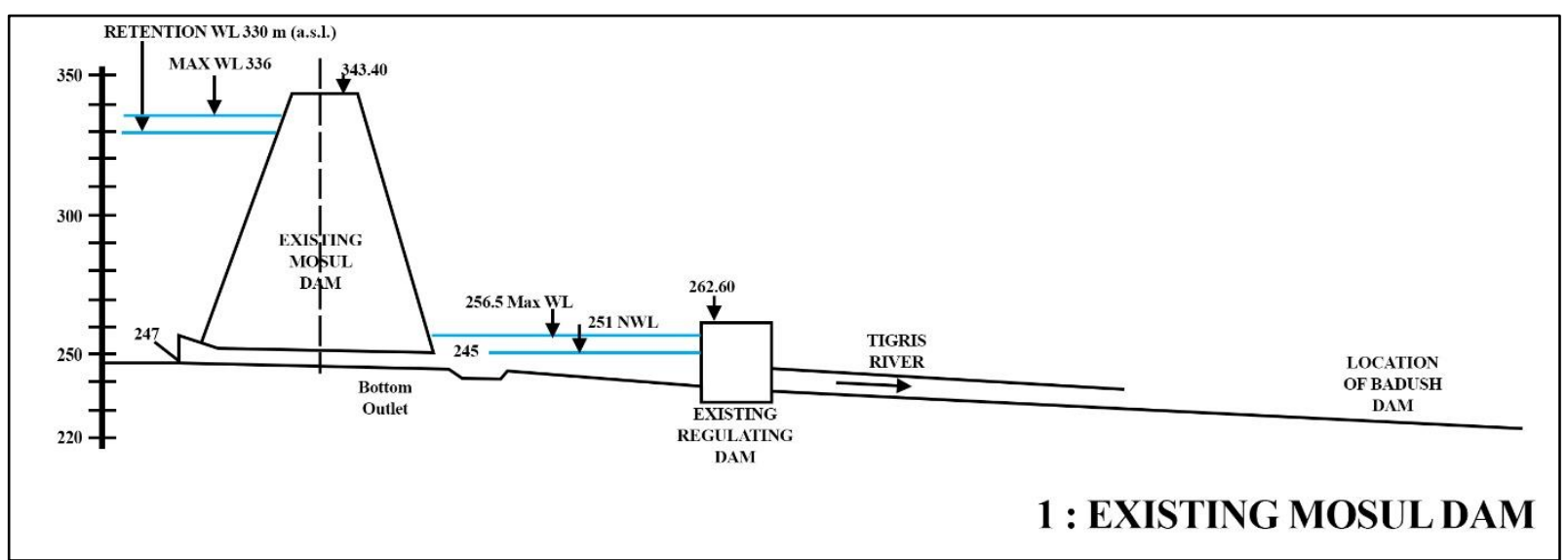

f.khajeek@ukh.edu.krd, nasrat.adamo@gmail.com, nadhir.alansari@ltu.se 


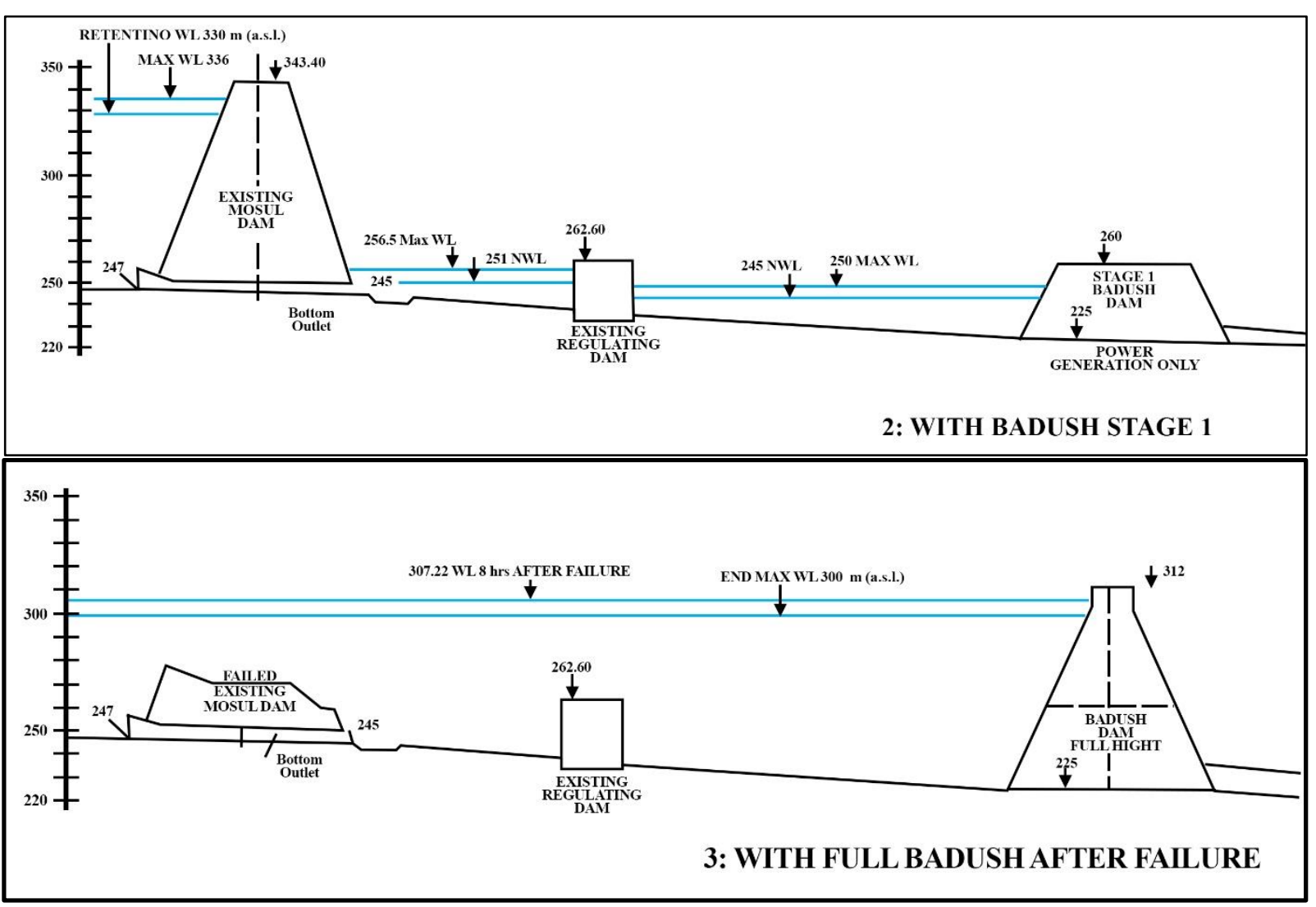

Fig. (7): Conceptual diagrams showing Badush Dam performance at different three phases (After Adamo et al., 2019)

\section{RESULTS}

Due to the karstification problems, which Mosul Dam suffers from, since its commissioning in 1986, in spite of the extensive grouting work being performed so far, it was suggested to construct a protection dam (Badush Dam) to protect the community and existing infrastructure downstream from Mosul Dam failure; if the dam would collapse. Accordingly, the Ministry of Water Resources, Baghdad, has asked ENERGPROJECT- Belgrade, to design a downstream protection dam. The location of the dam was chosen very quickly as the design of the dam and the construction of the dam started in 1988 but was abandoned in 1991 due to the First Gulf War and its consequences.

\section{DISCUSSION}

Badush Dam is planned and designed to be a protection dam and was under construction from 1988 - 1991. Whether the dam can function as a protection dam or otherwise, if it is decided to be completed, is discussed here. The geological conditions of Badush Dam site are the same as those of Mosul Dam (Fig. 2) which means Badush Dam will suffer from the same karstification dissolution problems as those present in Mosul Dam (Sissakian et al., 2014, 2018 a and b; Adamo et al., 2015 a and b; AlAnsari et al, 2015). This means that, extensive grouting may have to be done to the foundations in Badush Dam as it is the case in Mosul dam (Bonacci et al, 2009; Bonacci and Bonnaci, 2013; Adamo, et al., 2015). But it does not mean necessarily, however, that such grouting will stop the dissolution of the karstification at its foundations as the bed rock is also gypsum and the karst problems are well known to be very active (Sissakian and Abdul Jab'bar, 2005Johnson, 2008; Milanovic, 2011, Sissakian et al., 2014 and 2016; Al-Ansari et al., 2015 a). Accordingly, Badush Dam will not be in a safe condition, as designed, and will not be able to perform as a protection dam unless replacing the foundation grouting by a positive cutoff in the form of diaphragm. The dam embankment design should be revised also as the clay core and filters may prove to be very thin and not safe. (ENERGOPROJEKT, 1988).

f.khajeek@ukh.edu.krd, nasrat.adamo@gmail.com, nadhir.alansari@1tu.se 
Therefore, to have a safe dam and to perform successfully as a protection dam in its chosen location, the following recommendations should be taken in consideration:

1- To conduct detailed geological investigation at the dam site including, drilling and geophysical studies,

2- These studies should be carried out by well experienced staff with different specializations in order not to have misinterpreted data as it is the case in Mosul Dam (Sissakian et al, 2019), and

3- To change the design of the dam, especially that of the core and foundation treatment works, in order to be able to hold the flood wave in case of the collapse of Mosul Dam.

From the presented data, the best solution is to construct Badush Dam as a protection dam as it is planned and designed after performing the recommended changes, and not to think of it at any time as a multi-purpose dam functioning as normal dam. Moreover, to pass the trapped water from the collapsed Mosul Dam safely to downstream course of the Tigris River in a wellstudied and planned time duration.

\section{CONCLUSIONS}

From this study, the following can be concluded:

Badush Dam is planned and designed to be a protection dam in case of Mosul Dam collapse. As the site of Badush Dam is located on gypsum and limestone rocks of the Fatha Formation, which suffer from high degree of karstification, so the foundations will be impacted by the dissolution of this karstification creating unstable conditions for the dam. Grouting will not be effective as it has been proved so far in Mosul Dam. Therefore, the best decision for Badush Dam (if it is decided to be completed) is to continue the construction after performing the suggested modification to be able only to pass the flood wave from the collapsed Mosul Dam, which should be done in a planned time duration.

\section{Acknowledgment}

The authors express their sincere thanks to Mr. Hawkar A. Abdulhaq (University of Kurdistan Hewler) for enhancements of the figures.

\section{REFERENCES}

Adamo, N., Al-Ansari, N., Knutsson, S., Issa, A.I., Sissakian, V. And Knutsson, S., 2015 a. Mystery of Mosul Dam the most Dangerous
Dam in the World: Problems Encountered During and After Impounding the Reservoir. Journal of Earth Sciences and Geotechnical Engineering, Vol. 5, No.3, p. 47-58.

DOI:

www.divaportal.org/smash/record.jsf?pid=div a2:980979.

Adamo, N., Al-Ansari, N., Knutsson, S., Issa, A.I., Sissakian, V. And Knutsson, S., 2015 b. Mystery of Mosul Dam the most Dangerous Dam in the World: Maintenance Grouting. Journal of Earth Sciences and Geotechnical Engineering, Vol. 5, No.3, p. $71-77$.

DOI:

Www.scienpress.com/journal_focus.asp?main_ $\underline{\mathrm{id}=59 \& \text { Sub_id=IV\&volid=190. }}$.

Adamo, N., Al-Ansari, N., Knutsson, S., Laue, J. and Sissakian, V., 2017. Mosul Dam. A catastrophe yet to unfold. Engineering, Vol. 9, p. $263-278$.

DOI:

Www.scirp.org/journal/PaperInformation.aspx ?PaperID=75133.

Adamo, N., Al-Ansari, N., Sissakian, V.K., Laue, J. And Knutsson, S., 2019. Badush Dam: A Unique Case of Flood Wave Retention Dams Uncertain Future and Problematic Geology. Journal of Engineering, Vol. 11, p. 189- 205. https://doi.org/10.4236/eng.2019.114014.

Al-Ansari, N., Issa, I.E., Sissakian, V., Adamo, N. and Knutsson, S., 2015 a. Mystery of Mosul Dam the most Dangerous Dam in the World: Karstification and Sinkholes. Journal of Earth Sciences and Geotechnical Engineering, Vol. 5, No.3, p. 33 - 45, ISSN: $1792-9040$ (print), 1792-9660 (online) Scienpress Ltd. www.scienpress.com/Upload/GEO/Vol\%205_ 3_3.pdf.

Al-Ansari, N., Adamo, N., Sissakian, V.K. and Knotsson, S., 2015 b. Geological and Engineering Investigation of the Most Dangerous Dam in the World, Mosul Dam. Scienpress Ltd. ISBN 978-0-9934819. DOI=www.ltu.se/cms_fs/1.146950!/file/Mosul -Dam-Nadhir-Al-Ansari.

Bonacci, O. and Bonaci, T., 2013. The possible negative consequences of underground dam and reservoir construction and operation in coastal karst areas: an example of the hydroelectric power plant (HEPP) Ombla near Dubrovnik (Croatia). Natural Hazards Earth System Sciences, Vol. 13, p. 2041 - 2052.

DOI: $\quad$ www.nat-hazards-earth-systsci.net/13/2041/2013/doi:10.5194/nhess13.2041 .

Bonacci, O., Gottstein, S. and Roja- Bonacci, T., 2009. Negative impacts of grouting on the underground karst environment. Echohydrology, Vol.2, Issue 4, p. 492-502. DOI: $\quad$ www.nat-hazards-earth-systsci.net/13/2041/2013/nhess-13-2041-2013.pdf.

f.khajeek@ukh.edu.krd, nasrat.adamo@gmail.com, nadhir.alansari@ltu.se 
EDR GmbH, Cedre Team International, 2014. Badush Dam: Final Feasibility Study Report, October 2014.

ENERGOPROJEKT, 1988. Badush Dam Project 265, Feasibility Study, Preliminary Report for Badush Dam Project, Vol. 1. Mosul Dam Library, Mosul, Iraq.

Elconcord, Paul Rizzo, Energoprojekt, MED INGEGNERIA, 2009 a. Badush Dam Project Phase A: Analysis of Existing Works and Documentation”. Januaary, 2009.

Elconcord, Paul Rizzo, Energoprojekt, MED INGEGNERIA, 2009 b. Badush Dam Project Phase B: Design Adjustments and Final Design. November 2009. Badush Dam: Controversy and Future Possibilities 33.

Fouad, S.F., 2012. Tectonic Map of Iraq, scale $1: 1000000,3^{\text {rd }}$ edition. Iraq Geological Survey Publications, Baghdad, Iraq. DOI: www.scirp.org/ reference/ ReferencesPapers.aspx?Reference.

Fouad, S.F., Al-Shuwaily, A., Zainy, M. AlMousawi, H., Abdul Rahman, A., 2003. Detailed Geological Mapping Aiming for Native Sulphur Investigation in Mosul Badush vicinity. Iraq Geological Survey Library, internal unpublished report.

Hagopian, D.H. and Veljupek, M., 1977. Report on the regional geological mapping of Mosul Erbil Area. Iraq Geological Survey Library Report No. 843, 55 pp., Baghdad, Iraq.

Johnson, K.S., 2008. Gypsum-karst problems in constructing dams in the USA. USA Publications Warehouse. DOI: 10.1007/s00254-007-0720-z

Milanović, P., 2011. Dams and Reservoirs in Karst. In: Philip E. van Beynen (Editor), Karst Management. Springer, Dordrecht. DOI: sudartomas.files.wordpress.com/ 2012/11/karstmanagement.pdf

Muhi Al-Deen, R.M., Sissakian, V.K., Yousif, N.S., Amin, R.M. and Rofa, S.H., 1977. Report on the Regional Geological mapping of Mosul Tel Afar Area. Iraq Geological Survey Library Report No. 831, 65 pp., Baghdad, Iraq.

Sissakian, V.K. and Abdul-Jabbar, M.F., 2005. Site selection problems in gypsum-bearing formations. A case study from north of Iraq. Iraqi Bulletin of Geology and Mining, Vol. 1,

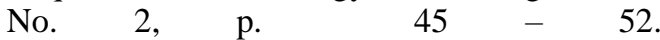
Iasj.net/iasj?func $=$ issues $\&$ jId $=225 \&$ uiLanguag $\mathrm{e}=\mathrm{en}$

Sissakian, V.K., Hagopian, D.A. and Hassan, E.A., 2013. Geological Map of Mosul Quadrangle, scale 1:250000, 2nd edition. Iraq Geological Survey Publications, Baghdad, Iraq.

Sissakian, V.K., Al-Ansari, N. and Knutson, S., 2014. Karstification problems in Mosul Dam and its assessment, North Iraq. Engineering. DOI: http://www.scirp.org/journal/eng.

Sissakian, V.K., Al-Ansari, N. and Knutson, S., 2015. Karst Forms in Iraq. Journal of Earth Sciences and Geotechnical Engineering, Vol. 5, No. 4, p. 1 - 26. DOI: www.diva portal.org/ smash/get/ diva2 :982702/FULLTEXT01.pd

Sissakian, V.K., Abdul Ahad, A.D., Al-Ansari, N. and Knutson, S., 2016. Factors controlling Karstification in the Fatha Formation in Iraq. Journal of Earth Sciences and Geotechnical Engineering, Vol.6, No. 3, p. 147 - 162. DOI: www.divaportal.org/smash/record.jsf?pid=diva2:981197.

Sissakian, V., Adamao, N., Al-Ansari, N., Knutsson, S. and Laue, J., 2017. Defects in Foundation Desigsn Due to Miss-Interpretation of the Geological Data. A Case Study of Mosul Dam. Scientific Research, Engineering, Vol. 9, No.7, p. 1 - 15. http://file.scirp.org/Html/58102857_78053.htm. https://doi.org/10.4236/ eng.2017.90742.

Sissakian, V., Adamo, N., Al-Ansari, N., Laue, J. and Knutsson, S., 2018 a. Geological and Geotechnical Study of Badush Dam, Iraq. Athens: ATINER'S Conference Paper Series, No: WAT2018-2546.

Sissakian, V.K., Adamo, N., Al-Ansari, N., Knutsson, S. and Laue, J., 2018 b. Badush Dam, NW Iraq: A Geological Study. Journal of Earth Sciences and Geotechnical Engineering, Vol. 8 , No. 2 , p. $1-15$.

Sissakian, V.K., Al-Ansari, N. and Adamo, N., 2019. The Role of Geological Investigations in Dam Siting. Mosul Dam a Case Study. Geotechnical and Geological Engineering, Vol. 38, p. 1 - 12. DOI:10.1007/s10706-01901150-2.

Swiss Consultants Consortium, 1985. Security Measures II, Addendum 3. Flood Wave Studies.Task 2, Mosul Flood Wave, Volumes $(1,2,3)$. Ministry of Irrigation, Baghdad, Iraq.

Thuro, K., Baumgartner, W. and Esslinger, W., 2000. Gypsum Karst problems along Alpine Motorway Tunnel. GeoEngineering. An International Conference on Geotechnical and Geological Engineering. Millburn, Australia. DOI: Www.geo.tum.de/ people/ thuro/pubs/2000_geoeng_fuessen.pdf.

U.S. Army Corps of Engineers, 2017. Engineering and Design. GROUTING TECHNOLOGY. Manual No. 1110-2-3506. EM 1110-2-3506. Washington D.C.

DOI:

www.publications.usace.army.mil/Portals/76/P ublications/EngineerManuals/EM_1110-23506.pdf.

Yacoub, S.Y. Othman, A.A. and Kadhum, T.H., 2011. Geomorphology. In: Geology of the Low Folded Zone. Iraqi Bulletin of Geology and Mining, Special Issue No. 5, p. 7 - 38.

DOI:

iasj.net/iasj?func=issues\&jId=225\&uiLanguag $\mathrm{e}=\mathrm{en}$.

f.khajeek@ukh.edu.krd, nasrat.adamo@gmail.com, nadhir.alansari@1tu.se

${ }^{1}$ Corresponding author: University of Kurdistan Hewler 